\title{
Beneficiation and Characterization of Gold from Itagunmodi Gold Ore by Cyanidation
}

\author{
Olasupo Daniel Ogundare1,2, Mosobalaje Oyebanji Adeoye², Adelana Rasaq Adetunji ${ }^{2,3}$, \\ Olusegun Oyeleke Adewoye 4 \\ ${ }^{1}$ Engineering Materials Development Institute, Akure, Nigeria \\ ${ }^{2}$ Department of Materials Science and Engineering, Obafemi Awolowo University, Ile-Ife, Nigeria \\ ${ }^{3}$ Prototype Engineering Development Institute, llesa, Nigeria \\ ${ }^{4}$ African University of Science and Technology, Abuja, Nigeria \\ Email: suppiedee@yahoo.com, madeoye@oauife.edu.ng, aderade2004@yahoo.com, oadewoye@yahoo.com
}

Received 8 May 2014; revised 25 June 2014; accepted 11 July 2014

Copyright (C) 2014 by authors and Scientific Research Publishing Inc.

This work is licensed under the Creative Commons Attribution International License (CC BY).

http://creativecommons.org/licenses/by/4.0/

c) (7) Open Access

\section{Abstract}

This paper has reported the beneficiation and characterization of gold from Itagunmodi gold ore in Atakumosa West LGA in the State of Osun Nigeria using cyanide solution obtained from cassava and commercially available sodium cyanide analar grade. Cyanide solution extracted from cassava variety TMS 30572 leaves obtained from Obafemi Awolowo University (O.A.U) Research and Teaching Farm was discovered to have the highest free cyanide ( $\left.\mathrm{CN}^{-}\right)$among the ten different cassava varieties evaluated. The samples were exposed to varied concentrations from $0.25 \%$ to $2.00 \%$ $\mathrm{CN}$ at intervals of $0.25 \% \mathrm{CN}$ from cyanide solution obtained from cassava and commercially available sodium cyanide analar grade. The result showed that after 24 hours of cyanidation and concentration of $2 \% \mathrm{CN}^{-}$on $10 \mathrm{~g}$ gold ore concentrate, the analar grade sodium cyanide yielded 0.123 $\mathrm{g}$ of gold while the cassava based cyanide yielded $0.098 \mathrm{~g}$. The cyanidation performance of analar grade sodium cyanide is greater than cassava based cyanide by a difference of $0.25 \%$.

\section{Keywords}

Gold, Cyanidation, Itagunmodi Gold Ore, Cassava, Commercial Sodium Cyanide, Cyanide from Cassava

\section{Introduction}

Over the last years, gold recovery has been the central issue in wide range of studies as a consequence of its high demand and value. These circumstances make the treatment of low-grade raw materials or refractory materials 
an interesting area of research. The most frequently used method for gold recovery is the cyanidation processes [1].

Generally, gold ores can be classified as "free milling" and "refractory" depending on their response to cyanide leaching [2]. While high gold recoveries ( $>90 \%)$ from free milling ores can be readily achieved, refractory gold ores are often characterized by the low gold extractions (50\% - 80\%) within a conventional cyanide leaching [3] [4]. The refractoriness of gold ores can result primarily from the inherent mineralogical features with particular reference to the mode of presence and association of gold, and to the presence of carbonaceous matter [3].

Gold in secondary deposits results from erosion of gold bearing rock structures, transportation of the eroded material by streams and deposition in placer form. This gold is usually in native and free form and can be easily recovered by conventional cyanidation. In primary (hydrothermal) deposits, magmatic processes have introduced and finely disseminated the gold into sulfide minerals such as pyrite and arsenopyrite; the gold occurs in a submicroscopic form and it is difficult to extract by conventional cyanidation even with fine grinding [5]-[7].

The use of ozone for gold extraction from a highly refractory concentrate has been reported [8]. They concluded that the ozone pretreatment also decreased the cyanide consumption due to the elimination of cyanide consuming sulfur species during the ozonization.

This work has reported the beneficiation efficiency of gold from Itagunmodi gold ore in Atakumosa West LGA in the State of Osun Nigeria using cyanide solution obtained from cassava and commercially available sodium cyanide analar grade.

\section{Materials and Methods}

\subsection{Materials}

All chemical reagents used in this work were of analytical grade and all stock solutions were prepared using distilled water. The gold ore samples were collected from two (2) selected pits from Itagunmodi in Atakumosa West LGA of Osun State. Ten different roots and leaves of different species of cassava were freshly harvested and prepared for analysis of cyanide content.

\subsection{Experimental Procedure and Techniques}

The physically processed ore (10 g) of sieve fraction 125 microns was weighed and poured into conical flask. There were 16 samples in the process. The first set of 8 was exposed to cyanidation with various concentrations of analytical grade $\mathrm{NaCN}$ solutions. The concentrations were varied from $0.25 \%$ to $2.00 \% \mathrm{CN}$ at intervals of $0.25 \% \mathrm{CN}$. The second set of 8 was treated with various concentrations of cyanide solutions from cassava, the concentrations also varying from $0.25 \% \mathrm{CN}$ to $2.00 \% \mathrm{CN}$ at intervals of $0.25 \% \mathrm{CN}$. Before each stage of cyanide addition in both sets, $0.5 \mathrm{~g}$ calcium (II) oxide (CaO), which provides "protective alkalinity" [9] was added to the conical flask containing the mixture and oxygen (atmospheric air) was passed into the conical flask using an improvised hand dryer. The $\mathrm{pH}$ of the slurry was raised to $\mathrm{pH} 10$ - 11 using $\mathrm{CaO}$ to ensure that when cyanide is added, hydrogen cyanide gas is not generated. Hence, the cyanide remained in solution and was available to dissolve the gold. In both sets, the cyanide solutions were added to the weighed samples, thoroughly stirred, and heated at $85^{\circ} \mathrm{C}$ [10] for one hour. The cyanide cell was left for 24 hours [11] [12].

$50 \mathrm{ml}$ concentrated $\mathrm{H}_{2} \mathrm{SO}_{4}$ was cautiously added to the mixture from the cyanidation lixiviation process and boiled for one hour at $50^{\circ} \mathrm{C}$ in a fume cupboard and taking all necessary precautions to avoid any violent reaction. The mixture was allowed to cool down for one hour and decanted. $100 \mathrm{ml}$ of de-ionised water was added to the mixture twice and then decanted in order to wash it to neutrality. The mixture was then washed with concentrated HCI so as to remove iron which usually co-precipitates with gold. Washing with HCI is an effective method for the removal of iron associated with gold [13]. Iron does dissolve and complex with cyanide solution along with gold. The weights of the samples were taken and recorded.

However, it was observed that there were still some impurities which added to its total weight. Hence, the need for further purification was a necessity. Each of the gold samples obtained using different cyanide concentrations was put in eight (8) pieces of $250 \mathrm{ml}$ beakers. Further refining was carried out by adding $10 \mathrm{ml} \mathrm{HNO}_{3}$ to the mixture and left for one hour in a fume cupboard at $50^{\circ} \mathrm{C}$. The acid was decanted and $100 \mathrm{ml}$ de-ionised water was added to the mixture twice and then decanted in order to wash it to neutrality. The residue was dried in the oven for one hour at $150^{\circ} \mathrm{C}$. The results of gold cyanidation tests carried out to leach gold using various lixiviants and precipitants are presented later in a figure. 
An X-ray diffractometer (XRD) (X'Pert Pro X-ray diffraction system Panalytical) was used to investigate the crystal structure of the samples. The samples were ground and pressed into the sample holder to get a smooth plane surface, and the diffraction pattern was recorded over a $2 \theta$ range of $30^{\circ}-120^{\circ}$. The diffractogram obtained was compared to the standard database of the International Centre for Diffraction Data (ICDD).

The morphological features of the samples were studied with a scanning electron microscope (SEM) JEOL Model JSM-7600F.

\section{Results and Discussion}

The XRD of the gold ore showed a lot of diffraction peaks with numerous background noise. This could be due to presence of numerous associated mineral oxides in the gold ore (Figure 1(a)). The relative phase amounts (wt\%) estimated using the Rietveld method revealed the presence of quartz (50\%), Illmenite (45\%) and low amount of gold (below the detection limit). The low content of gold and the size of the particles (top trace) are too small to provoke measurable reflections in the XRD. This is in tandem with the EDXRFS that showed that the gold ore contained about 19 ppm gold. The broad peaks observed revealed some amorphous property of the gold ore. In Figure 1(b), there was zero background noise. The diffraction peaks are sharp and well defined indicating that the extracted old is crystalline in nature. The only crystalline phase present is gold because almost all the other undesirable mineral compounds have been removed through cyanidation.

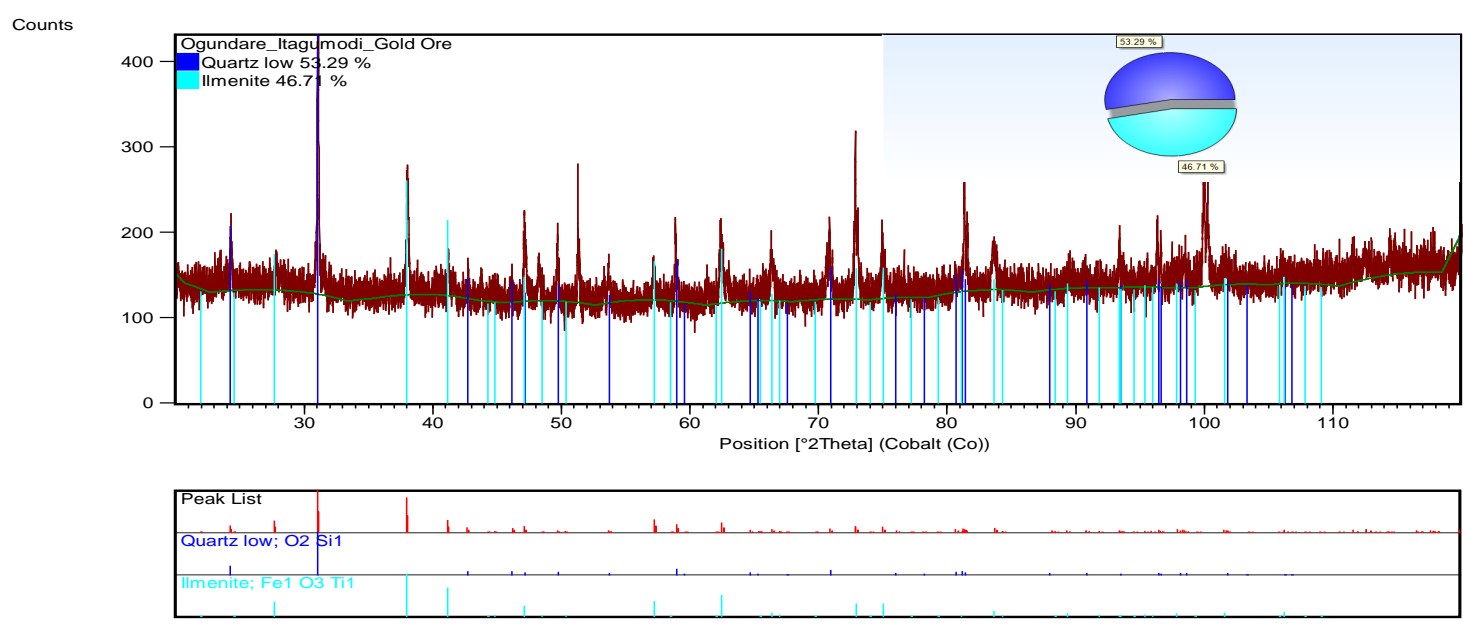

(a)
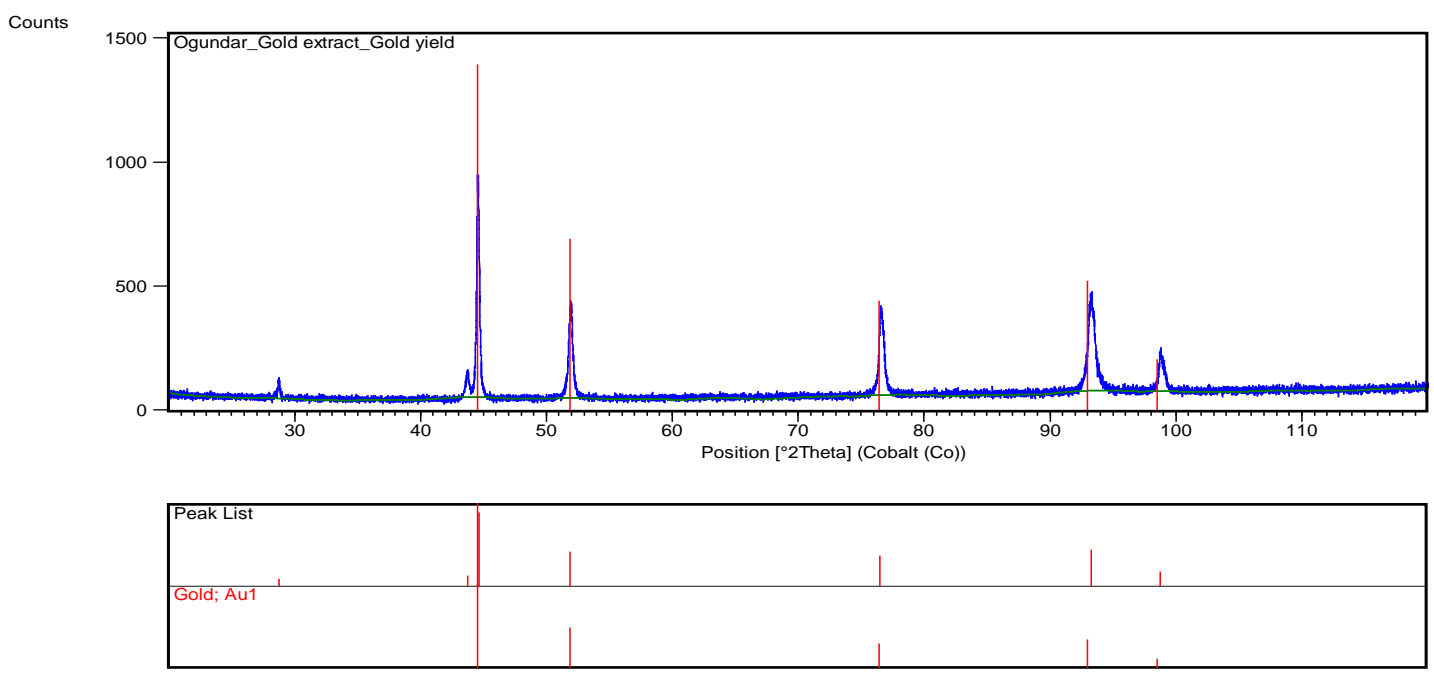

(b)

Figure 1. XRD pattern of (a) gold ore and (b) gold extract through cyanidation. 
In Figure 1(a), which shows the gold ore, about eighteen (18) peaks starting from $2 \theta=15^{\circ}$ to $2 \theta=100^{\circ}$ were observed while the extracted gold shown in Figure 1 (b) revealed about five (5) peaks starting from $2 \theta=45^{\circ}$ to $2 \theta=100^{\circ}$.

The SEM (Plate 1(a) and Plate 1(c)) shows that the morphology of the particles of gold ore from Itagunmodi deposit is in trihedron shapes. The SEM (in Plate 1(b) and Plate 1(d)) image shows the morphology of the particles of gold extracted in tetrahedron and hexahedron shapes. The distribution of the particles in the gold ore revealed that they are inhomogeneous and that more of the particles size falls within $100 \mu \mathrm{m}$ (Figure 2(a)). The average particle size was evaluated statistically to be $106 \mu \mathrm{m}$. From Figure 2(b), however, the particle size distribution is more homogeneous than we have in Figure 2(a). This may be attributed to presence of many undesirable minerals of unequal sizes that made up the gold ore. The extracted gold with particles size of $200 \mu \mathrm{m}$, $500 \mu \mathrm{m}$ and $600 \mu \mathrm{m}$ occupied 13\% volume fraction each while the particle size of $200 \mu \mathrm{m}, 400 \mu \mathrm{m}$ and $900 \mu \mathrm{m}$ are occupying $11 \%$ volume fraction. The average particle size was evaluated statistically to be $412 \mu \mathrm{m}$ confirming that the extracted gold has larger particle size than the gold ore. This is also supported by the SEM images shown in Plate 1.

Plate 2 shows the photo-microscopy of the gold yield leached using various concentrations of sodium cyanide $(\mathrm{NaCN})$ and cyanide solution from cassava. It can be observed that the yellowish portion of each micrograph showed a gradual increase in the quantity of gold leached as the concentrations of sodium cyanide $(\mathrm{NaCN})$ and cyanide solution from cassava increase.

Figure 3 shows the result of the gold cyanidation procedure using cyanide solution extracted from cassava and the commercially available sodium cyanide analar grade. It can be observed that as the concentration of the lixiviants increased, the gold yield obtained increased. It should be noted that further refining of the earlier gold yield was accomplished by acid leaching $\left(\mathrm{HNO}_{3}\right)$ and consequently led to increased gold yield. This is because $\mathrm{HNO}_{3}$ is a more powerful oxidizing agent than $\mathrm{H}_{2} \mathrm{SO}_{4}$.

The mechanism of cyanide lixiviation is as schematized below:

$$
2 \mathrm{Au}_{(\mathrm{s})}+4 \mathrm{CN}^{-}{ }_{(\mathrm{aq})}+\mathrm{H}_{2} \mathrm{O}+\frac{1}{2} \mathrm{O}_{2} \rightarrow 2\left[\mathrm{Au}(\mathrm{CN})_{2}^{-}\right]_{(\mathrm{aq})}+2 \mathrm{OH}_{(\text {(aq) }}^{-}
$$

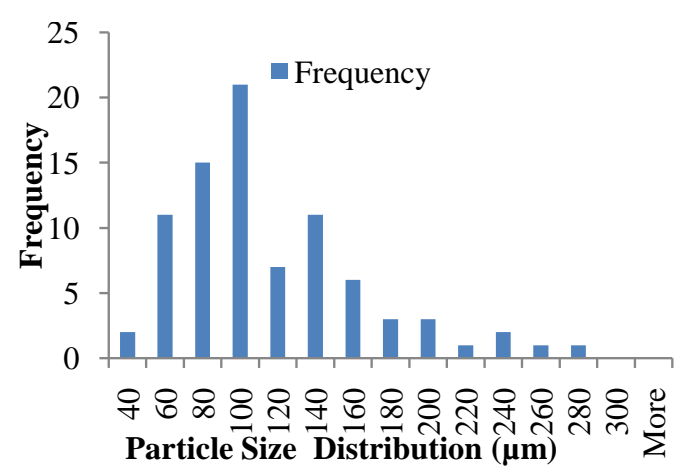

(a)

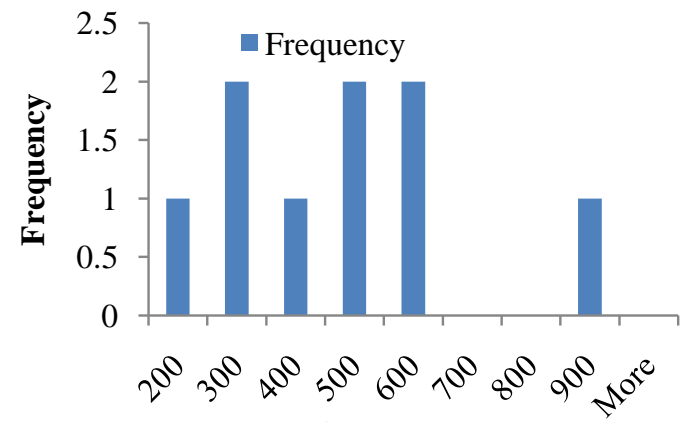

Particle Size Distribution ( $\mu \mathrm{m})$

(b)

Figure 2. Particle size distribution of the gold ore (a) and the extracted gold (b).

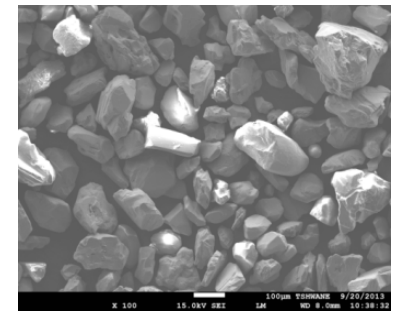

(a)

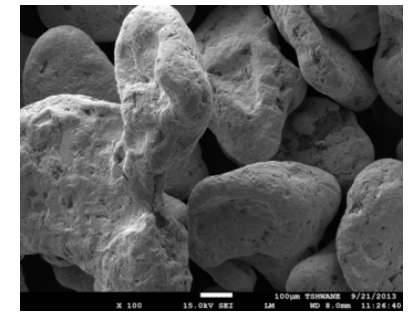

(b)

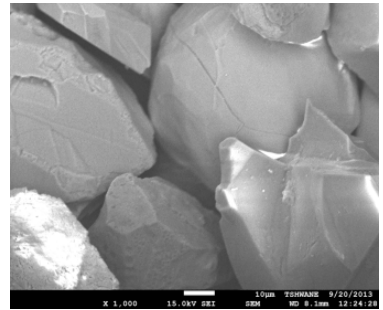

(c)

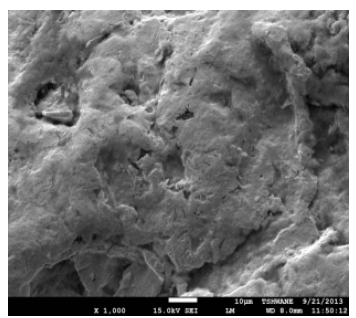

(d)

Plate 1. SEM images of the morphologies of the gold ore $(a)(\times 100)$; $(c)(\times 1000)$ and the extracted gold grains $($ b) $(\times 100)$; (d) $(\times 1000)$. 


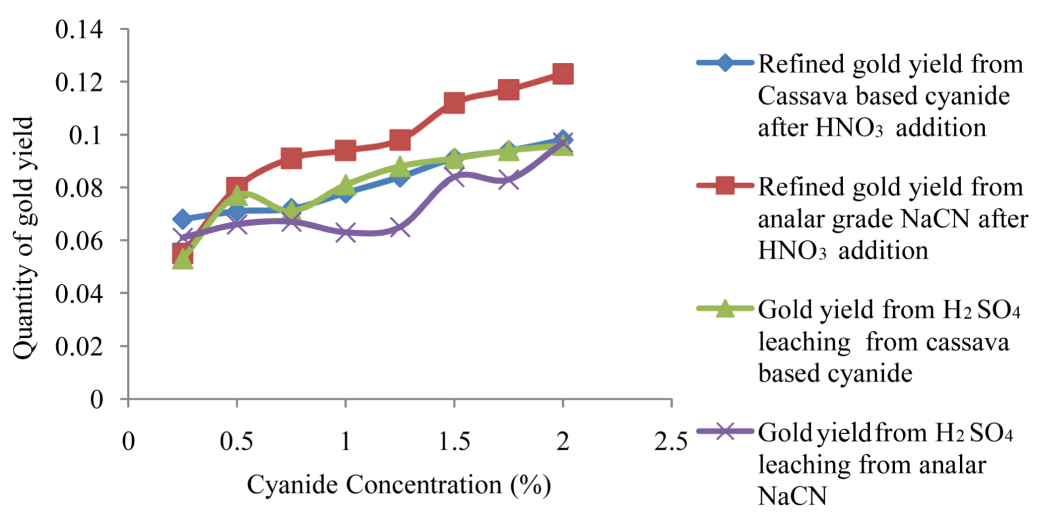

Figure 3. Gold cyanidation test.

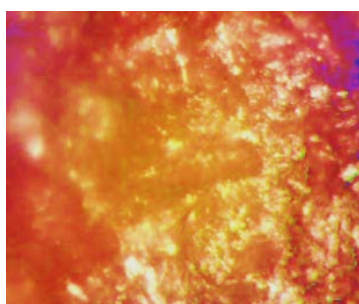

$0.25 \% \mathrm{NaCN}$

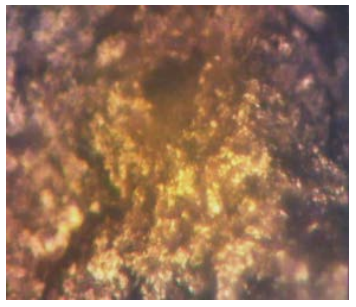

$1.25 \% \mathrm{NaCN}$

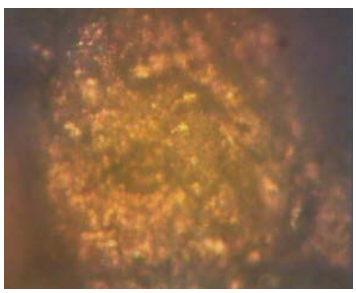

$0.5 \% \mathrm{CN}^{-}$from cassava

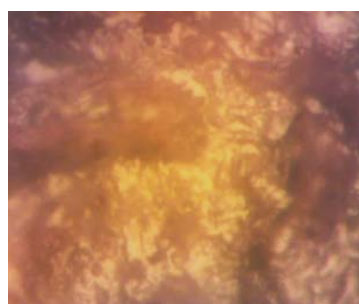

$0.5 \% \mathrm{NaCN}$

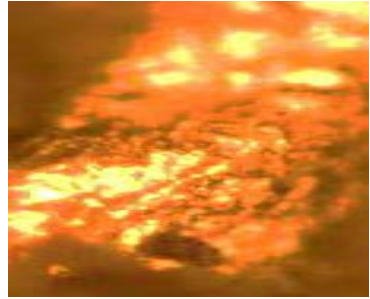

$1.5 \% \mathrm{NaCN}$

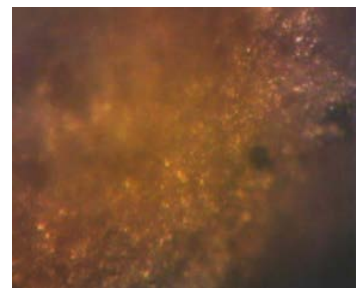

$0.75 \% \mathrm{CN}^{-}$from cassava

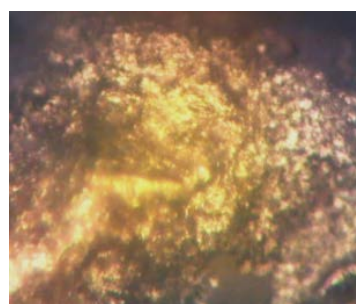

$0.75 \% \mathrm{NaCN}$

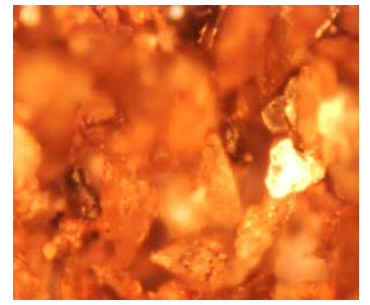

$2 \% \mathrm{NaCN}$

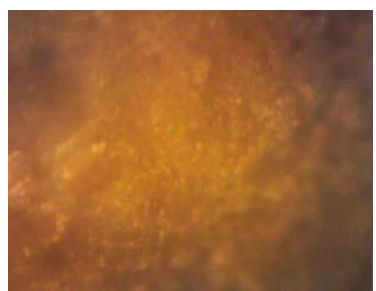

$1 \% \mathrm{CN}^{-}$from cassava

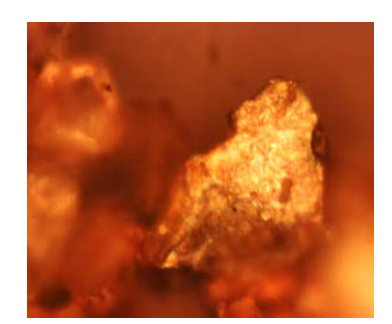

$2 \% \mathrm{CN}^{-}$from cassava

$(\times 100)$.

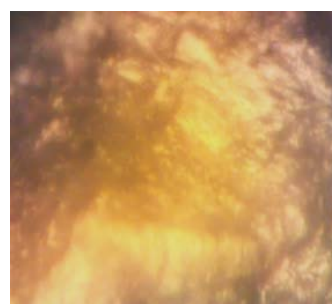

$1 \% \mathrm{NaCN}$

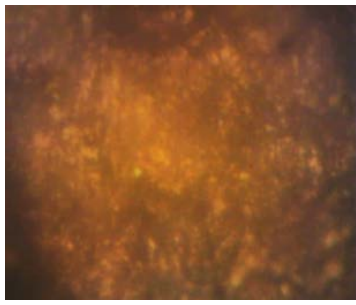

$0.25 \% \mathrm{CN}^{-}$from cassava

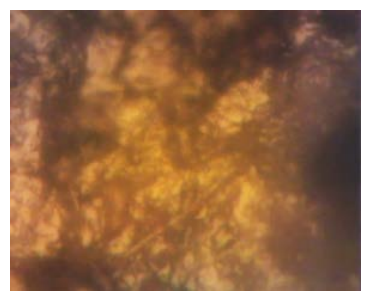

$1.25 \% \mathrm{CN}^{-}$from cassava

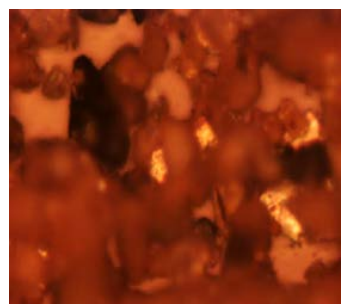

$1.5 \% \mathrm{CN}^{-}$from cassava

$$
2\left[\mathrm{Au}(\mathrm{CN})_{2}^{-}\right]_{(\mathrm{aq})}+2 \mathrm{OH}_{\text {(aq) }}^{-}+\mathrm{H}_{2} \mathrm{SO}_{4(\mathrm{aq})}+\frac{1}{2} \mathrm{O}_{2(\mathrm{~g})} \rightarrow 2 \mathrm{Au}_{(\mathrm{s})}+\mathrm{SO}_{4}^{-}+4 \mathrm{HCN}_{(\mathrm{l})}
$$




$$
\begin{gathered}
2 \mathrm{Au}_{(\mathrm{s})}+\mathrm{SO}_{4}^{-}+4 \mathrm{HCN}_{(\mathrm{l})}+\mathrm{H}_{2} \mathrm{O} \rightarrow 2 \mathrm{Au}_{(\mathrm{s})}+2 \mathrm{HCl} \\
\mathrm{Au}_{(\mathrm{s})}+2 \mathrm{HCl} \rightarrow \mathrm{AuCl}_{2}+\mathrm{H}_{2}
\end{gathered}
$$

After 24 hours of cyanidation and analar grade sodium cyanide concentration of 2\%, 10 g gold ore concentrate yielded $0.123 \mathrm{~g}$ (123 mg). Also, under the same condition and using cassava based cyanide concentration of $2 \%, 10$ g gold ore concentrate yielded $0.098 \mathrm{~g}$ (98 mg). The percentage yield of gold from Itagunmodi gold ore, Ilesa-Nigeria and those from the other countries are as presented below in Table 1. These results have shown that the Itagunmodi (Nigeria) gold ore deposit is richer in native gold particles than those of Igun (Nigeria), Australia and Saudi Arabia deposits. According to [9] and [14], Australia and Saudi Arabia deposits contain mainlygold in the form of gold sulphide. The sulphide ore did not allow the direct attack of the gold particles by the cyanide solution in the ore because gold particles were locked in the sulphides.

Extraction of gold from Igun deposit did not pass through acid leaching after cyanidation to unlock the residual gold particles.

On the gold yield, with $2 \%$ concentration of analar grade sodium cyanide, $1.23 \%$ gold was recovered while with $2 \%$ concentration of cassava based cyanide, $0.98 \%$ was recovered. In terms of gold recovery efficiency, the performance of analar grade sodium cyanide was greater than cassava based cyanide by a difference of $0.25 \%$. Table 2 shows the EDXRFS result of Itagunmodi gold ore, gold extracted using 2\% sodium cyanide analar grade and $2 \%$ cyanide obtained from cassava respectively. The chemical analysis showed that Itagunmodi gold ore and gold extract contain magnesium, aluminium, silicon, phosphorus, sulphur, potassium, calcium, titanium, vanadium, chromium, manganese, cobalt, iron, nickel, copper, zinc, arsenic, yittirium, lead, tungsten, gold, silver and rhobium. The presence of these associated minerals has been earlier reported by [15]-[17]. It can be observed that only the gold yield or extract from $2 \%$ concentration of sodium cyanide analar grade and $2 \%$ cyanide obtained from cassava was examined using EDXRFS because they produced the highest gold recovery efficiency. One striking feature is that the high quantity of iron (Fe) discovered in the ore (23\%) was as a result of the large composition of laterite sand in the ore during mining process. The high quantity of iron was observed to have been drastically reduced after cyanidation process to $0.56 \%$ and $0.89 \%$ respectively. Also, titanium oxide which was found in high quantity (31\%) in the ore has been reduced after the cyanidation process to $0.3 \%$ and $0.5 \%$ respectively. However, it is surprising to observe a sudden increase in the amount of tungsten oxide from $6 \%$ in the ore to about $102 \%$ and $91 \%$ respectively. This may be due to difference in instrumentation error. The gold oxide was observed to increase from $19 \%$ in the gold ore to $209 \%$ and $192 \%$ respectively. This can be attributed to the acid leaching process after cyanidation in order to accomplished better purity of the obtained gold particles.

\section{Conclusions}

- After 24 hours of cyanidation and concentration of $2 \% \mathrm{CN}$ on 10 g gold ore concentrate, the analar grade sodium cyanide yielded $0.123 \mathrm{~g}$ while the cassava based cyanide yielded $0.098 \mathrm{~g}$. The performance of analar grade sodium cyanide is greater than cassava based cyanide by a difference of $0.25 \%$.

- The SEM shows that the morphology of the particles of gold ore from Itagunmodi deposit is in trihedron shapes while the morphology of gold extracted from the gold ore is in tetrahedron and hexahedron shapes.

- The average particle size of the gold ore was evaluated statistically to be $106 \mu \mathrm{m}$ while that of the gold extracted was found to be $412 \mu \mathrm{m}$.

- The particles size distribution revealed that the gold extracted had better homogeneity than that of the gold ore.

Table 1. Comparison of the percentage yield of gold from Itagunmodi gold ore with other deposits.

\begin{tabular}{ccc} 
Country & Yield (mg/100g of ore) & $\%$ yield \\
\hline Itagunmodi, Atakumosa West LGA (Nigeria) & $1230 / 980$ & $1.23 / 0.98$ \\
Itagunmodi, Atakumosa West LGA (Nigeria) [11] & $27.2 / 16.48$ & $0.27 / 0.16$ \\
Igun, Atakumosa West LGA (Nigeria) [17] & 33.00 & 0.0330 \\
Papua, Australia [9] & 2.86 & 0.00286 \\
Mahd Adh Dhahab Saudi Arabia [14] & 2.60 & 0.00260 \\
\hline
\end{tabular}


Table 2. Energy dispersive-X ray fluorescence spectrometry.

\begin{tabular}{|c|c|c|c|}
\hline \multirow{2}{*}{ Element } & Gold ore & Gold extracted using $2 \%$ sodium cyanide analar & Gold extracted using $2 \%$ cassava based cyanide \\
\hline & Content (ppm) & Content (ppm) & Content (ppm) \\
\hline $\mathrm{Mg}$ & 0.0478 & 0.4507 & 0.3081 \\
\hline $\mathrm{Al}$ & 0.6538 & 0.7153 & 0.5887 \\
\hline $\mathrm{Si}$ & 2.1584 & 0.6043 & 0.5367 \\
\hline$P$ & 0.4485 & 2.2342 & 2.0426 \\
\hline S & 0.3998 & 7.0327 & 6.1424 \\
\hline $\mathrm{K}$ & 0.0000 & 0.0000 & 0.0000 \\
\hline $\mathrm{Ca}$ & 0.2197 & 0.0593 & 0.0757 \\
\hline $\mathrm{Ti}$ & 30.9081 & 0.2533 & 0.5112 \\
\hline $\mathrm{V}$ & 0.2328 & 0.0079 & 0.0114 \\
\hline $\mathrm{Cr}$ & 0.0000 & 0.0021 & 0.0011 \\
\hline $\mathrm{Mn}$ & 0.7312 & 0.0099 & 0.0201 \\
\hline Co & 0.0039 & 0.0030 & 0.0000 \\
\hline $\mathrm{Fe}$ & 23.1568 & 0.5682 & 0.8987 \\
\hline $\mathrm{Ni}$ & 0.0609 & 0.0412 & 0.0450 \\
\hline $\mathrm{Cu}$ & 0.0661 & 0.0646 & 0.0875 \\
\hline $\mathrm{Zn}$ & 0.1021 & 0.2687 & 0.2682 \\
\hline As & 0.0000 & 0.0000 & 0.0000 \\
\hline $\mathrm{Pb}$ & 0.0156 & 0.0000 & 0.0000 \\
\hline W & 6.1191 & 102.4461 & 90.5610 \\
\hline $\mathrm{Au}$ & 19.0095 & 208.6410 & 191.9714 \\
\hline Ag & 0.0362 & 0.0186 & 0.0240 \\
\hline $\mathrm{Rb}$ & 0.0091 & 0.2900 & 0.2619 \\
\hline
\end{tabular}

\section{Acknowledgements}

The authors are grateful to Engineering Materials Development Institute (EMDI) Akure Nigeria for the bench work, National Agency for Science and Engineering Infrastructure (NASENI) Abuja Nigeria and International Foundation for Science (IFS) Stockolm, Sweden for the funding. We are grateful for cassava samples from Obafemi Awolowo University Ile Ife, Federal University of Technology Akure and Federal College of Agriculture Akure and International Institute for Tropical Agriculture Ibadan Research and Teaching Farms.

\section{References}

[1] Ojeda, M.W., Perino, E. and Ruiz, M.C. (2009) Gold Extraction by Chlorination Using a Pyrometallurgical Process. Minerals Engineering, 22, 409-411. http://dx.doi.org/10.1016/j.mineng.2008.09.002

[2] La Brooy, S.R., Linge, H.G. and Walker, G.S. (1994) Review of Gold Extraction from Ores. Minerals Engineering, 7, 1213-1241. http://dx.doi.org/10.1016/0892-6875(94)90114-7

[3] Rubisov, D.H., Papengelakis, V.G. and Kondos, P.D. (1996) Fundamental Kinetic Models for Gold Ore Cyanide Leaching. Canadian Metallurgical Quarterly, 35, 353-361. http://dx.doi.org/10.1179/cmq.1996.35.4.353

[4] Adams, M.D. (2005) Advances in Gold Ore Processing, Developments in Mineral Processing. Elsevier, Amsterdam. 
[5] Chryssoulis, S.L. and McMullen, J. (2005) Mineralogical Investigation of Gold Ores. In: Adams, M.D., Ed., Advances in Gold Ore Processing, Elsevier, The Netherlands, 21-71. http://dx.doi.org/10.1016/S0167-4528(05)15002-9

[6] Chen, T., Cabri, J. and Dutrizac, E. (2002) Characterizing Gold in Refractory Sulfide Gold Ores and Residues. Journal of Minerals, Metallurgy and Materials, 54, 20-22.

[7] Demopoulos, P. and Papangelakis, G. (1987) Acidic Pressure Oxidation of Refractory Gold Minerals Carriers. International Symposium on Gold Metallurgy, Winnipeg, 341-357.

[8] González-Anaya, J.A., Nava-Alonso, F. and Pecina-Treviño, E.T. (2011) Use of Ozone for Gold Extraction from a Highly Refractory Concentrate. Ozone: Science \& Engineering, 33, 42-49. http://dx.doi.org/10.1080/01919512.2011.536507

[9] Robinson, P.C. (1983) Mineralogy and Treatment of Refractory Gold from the Porgera Deposit, Papau New Guinea. Australia Mineral Processing and Extractive Matellurgy, Institution of Mining and Metallurgy, Transactions, Section C, 92, 87-91.

[10] Habashi, F. (1970) Extractive Metallurgy; Gordon and Breach. Vol. 2, Science Publishers Inc, NY, 24-56.

[11] Adetunji, A.R. (1991) Use of Cyanide Solution from Cassava for the Extraction of Gold. M.Sc. Thesis (Unpublished), Obafemi Awolowo University, Ile-Ife.

[12] Celep, O., Alp, I., Deveci, H. and Vicil, M. (2008) Characterization of Refractory Behavior of Complex Gold/Silver Ore by Diagnostic Leaching. Transactions of Non-Ferrous Metals Society of China, 19, 707-713. http://dx.doi.org/10.1016/S1003-6326(08)60337-4

[13] Bello, A.A. (1997) Extraction of Gold from Ilesa Gold Ore Deposit. M.Sc. Thesis (Unpublished), University of Ilorin, Ilorin.

[14] Lewis, P.J. and Martin, G.T. (1983) Gold-Silver Deposit, Saudi Arabia; Mineralogical Studies Associated with Metallurgical Process Evaluation, Mineral Processing and Extractive Metallurgy. Transactions, Mahd Adh Dhahab, Section C, 92, 63-68.

[15] Ariyibi, E.A., Folami, S.L., Ako, B.D., Ajayi, T.R. and Adelusi, A.O. (2011) Application of the Principal Component Analysis on Geochemical Data: A Case Study in the Basement Complex of Southern Ilesa Area, Nigeria. Arab Journal of Geosciences, 4, 239-247. http://dx.doi.org/10.1007/s12517-010-0175-5

[16] Elueze, A.A. (1997) Geological and Geochemical Studies in the Ilesa Schist Belt in Relation to Gold Mineralization. M.Phil. Thesis (Unpublished), University of Ibadan, Ibadan.

[17] Mesubi, M.A., Adekola, F.A., Bello, A.A., Adekeye, J.I.D. and Bale, R.B. (1999) Extraction of Gold from Igun Gold Ore Deposit in Atakumosa Local Government Area, Osun State, Nigeria. Nigeria Journal of Pure and Applied Science, 14, 935-945. 
Scientific Research Publishing (SCIRP) is one of the largest Open Access journal publishers. It is currently publishing more than 200 open access, online, peer-reviewed journals covering a wide range of academic disciplines. SCIRP serves the worldwide academic communities and contributes to the progress and application of science with its publication.

Other selected journals from SCIRP are listed as below. Submit your manuscript to us via either submit@scirp.org or Online Submission Portal.
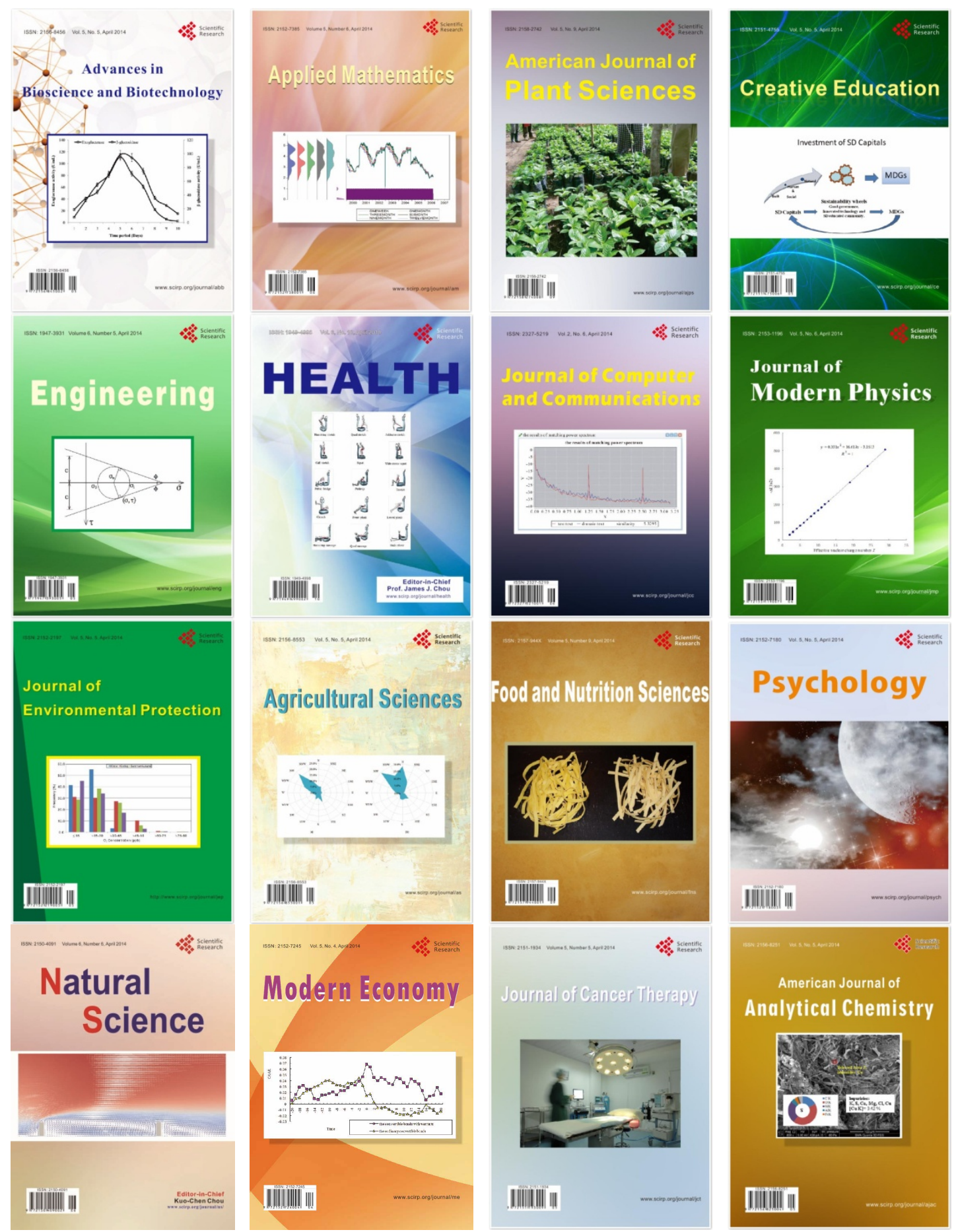